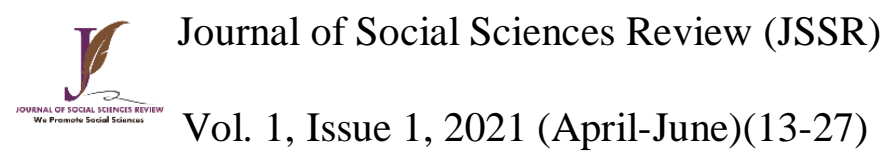

\title{
Classroom management practices of secondary school teachers in district Swat
}

\author{
Asad Iqbal ${ }^{1}$, Dr. Atta Ullah² and Alam Zeb ${ }^{3 *}$ \\ ${ }^{1}$ B.ED student at the Center for Education \& Staff Training University of Swat 19200, Pakistan \\ ${ }^{2}$ Department of Education, Shaheed Benazir Bhutto University, Dir Upper18000 Pakistan, \\ 3* Center for Education \& Staff Training University of Swat 19200, Pakistan
}

\begin{abstract}
Author/s Note
We (the authors) agree with the journal's open access policy, and we have no conflict of interest. This research received no specific grant from any funding agency, commercial or not-for-profit sectors. Correspondence concerning this article should be addressed to Center for Education and Staff Training, University of Swat 19200, Pakistan, Contact: alamzeb@uswat.edu.pk
\end{abstract}




\begin{abstract}
The study's goal was to examine secondary school teachers' classroom management methods. Findings from this research will help secondary school instructors improve their classroom management, as well as identifying and resolving difficulties in the classroom management of secondary school teachers. There were 5623 male secondary school teachers in Swat who participated in the survey. To conduct the study, the researchers picked 100 instructors at random using basic random selection and then created a questionnaire to gather data from them. Researchers used self-administered surveys to collect the information, which was then evaluated using frequency, percentages, and the Chi-square test, among other methods. Using body language to curb misbehaviour in their classrooms was shown to be a classroom management strategy used by instructors in their classrooms, according to a research. Approaches for successful classroom management were discovered, including interactive discussion, rulemaking in cooperation with students, allocating responsibilities to students, and providing a pleasurable atmosphere in courses for students to form rapport.Keywords: classroom management, district Swat, practices, secondary schools teachers
\end{abstract}


There are several factors that go into efficient classroom management, including compelling content, student accountability, suitable teaching model implementation, effective instruction and management abilities. The aforementioned description encompasses a wide range of activities that take place in classrooms, such as a curriculum that keeps students actively engaged in their studies, instructors who are experts in their fields and can effectively educate their charges. Elizabeth (2018) defines classroom management as the range of skills and practises instructors employ to keep their classroom running smoothly, without interruption. Classroom management, as defined by Brophy (2006), is the process of organising the physical environment, setting rules and procedures, and ensuring that students are paying attention and actively participating in class activities in order to create and maintain a positive learning environment.

When it comes to creating an atmosphere conducive to learning, Masrur (2015) believes that one way to do this is to ensure that the students are actively involved in all aspects of classroom administration. According to Afzal (2015), classroom management is the art of structuring a place where a group of individuals has the resources, time, and reasons accessible to nurture, encourage, and respect their learning of a restricted set of knowledge and ideas. This term encompasses a wide range of classroom activities, including the management of time, resources, and knowledge acquisition. It's impossible to separate the classroom atmosphere from these aspects of the experience. At the very least, one individual is sufficient to create a learning environment.

Classroom management is defined by Osama (2012) as instructors' impressions of their work environment, which is impacted by formal and informal connections, personalities of 
participants, and leadership in the workplace. While the physical environment plays an important role, Galbraith (1990) suggests that classroom management is also a matter of establishing a supportive and challenging, pleasant, casual, and open culture in the first session.

Korpershoek (2016) was shown at the 2016 Cannes Film Festival Activities that instructors may utilise in the classroom to create an atmosphere that might include anything from activities to enhancements and rules for governing student-teacher interactions are called classroom management techniques. There are two types of classroom management strategies: preventative and responsive. Oliver (2007) argues that a systematic approach to teacher preparation and ongoing professional development is needed to improve teachers' ability to manage classrooms effectively. He is a firm believer in the value of on-going training for all instructors, but especially for new ones. Students are more likely to fail at school because new instructors lack sufficient classroom management training and are more prone to punish students for misconduct. Professional development and classroom management training are vital for teachers who deal with kids who misbehave because they will be better able to control their classrooms.

Discipline issues are a major source of frustration for educators. Students often arrive late, are not on time, and are interested in lessons. He believes that these issues can only be solved by a teacher who is prepared for the class, who can encourage and give significant environments for the student's creativity. Long-term classroom management and long-term responsibilities need a strong willingness on the part of teachers. According to Masrur(2015), classroom conduct may be influenced by establishing clear rules and communicating the 
consequences of violating those rules to students. It is hoped that rewarding good conduct and punishing poor behaviour would lead to an increase in good behaviour. Reward has an important impact in the academic and social conduct of pupils in the classroom.

According to Linsin(2015), the best classroom management tactics are a blend of mild but powerful strategies designed to establish a school environment that encourages learning and satisfaction. In the end, it's about a sense of self-confidence, a willingness to influence others, and the ability to treat kids with respect. However, austerity is only included in the sense that clearly established norms of behaviour are carefully upheld in order to protect both learning and enjoyment. According to the research of Akomolafe (2015), the atmosphere of the classroom has a substantial impact on how students learn and how teachers teach. Classroom teaching is the primary mode of implementing the curriculum or syllabus. Several secondary school topics' learning outcomes will be influenced by the quality of their teachers' instruction, in part because of the conditions in the classroom. It is true that the classroom setting has an impact on student comprehension and learning quality. If the classroom's physical environment meets the needs of the students, the lessons will be more relevant, but if it doesn't, the kids will suffer. Middle and high school instructors in general and elementary school teachers in particular have a difficult time dealing with the classroom atmosphere.

Since the first classroom was identified, classroom management has been an issue. Classroom management is becoming more important as educators and administrators work to provide a supportive learning environment for students as the need to raise student achievement mounts (Rosas \& West,2009). Classroom management tactics are in the hands of the instructors, 
according to educators and researchers. This has created the ideal scenario for teachers to establish the norms and importance of inappropriate conduct (Frieberg \& Lamb, 2009).

Traditional classroom management methods are used by certain educators. As class numbers continue to rise, instructors have the problem of ensuring that a significant number of kids are successful (Adams, 2011). Researchers Regina and Oliver (2007) claim that strengthening the ability of classroom management instructors requires a systematic approach to teacher preparation and current professional development. He thinks that teachers in general and new teachers in particular need constant professional development. When a kid misbehaves at school, new instructors lack sufficient classroom management training and are more inclined to punish the student rather than help him or her succeed academically. It is possible to infer that professional development and training are necessary to handle kids with misbehaviour since the teacher involved will be able to manage the classroom more successfully.

Teachers' ability to effectively manage their classrooms has a direct impact on the quality of their instruction and the success of their pupils. Because of the significance of classroom management practises for secondary school students' learning, the research sought to examine secondary school teaching practises and design effective classroom management practises for the secondary school classroom environment. Students' performance is indirectly affected by classroom management's ability to moderate disciplinary measures. Individual differences and even bullying in the classroom may be dealt with via classroom management. Classroom management saves both student and teacher resources while also enhancing learning opportunities in the classroom. 


\section{METHODOLOGY}

\section{Population Sample and Sampling}

The study's population included 5623 male secondary school teachers in District Swat. Among the whole population, there were 1344 SST and 4279 CTs. The researchers used basic random selection to choose a sample of 100 instructors to gather data on the issue. Using simple random sample was advised since the population was homogeneous in character, hence random sampling was employed.

\section{Instrumentation}

To gather data, the researchers looked at the relevant literature and created a questionnaire. The questionnaire included two sections. Teachers at the secondary level were the subject of the first part of this article, which focused on how they manage their classrooms. In order to verify its dependability, the researchers used expert opinion to evaluate the questionnaire, made adjustments, and then ran a pilot test with 30 instructors. The results were then entered into SPSS version 22 for analysis. The.842 level of confidence was obtained. The people who took part in the piloting phase were excluded from the study's final analysis.

Gathering and analysing of information

Research participants completed self-administered questionnaires to provide the researchers with data, and they were given an explanation of the study's goals. By using SPSS, tables were produced as well as chi-square tests were used to examine data. The Chi-square test was used to analyse the data since it was categorical in nature. 


\section{Results and discussion}

Table 1

Classroom Management Practices of Secondary Schools' teachers

$\begin{array}{llllll}\text { Statements } & \text { A } & \text { UD } & \text { D } & \chi^{2} & \text { P }\end{array}$

\begin{tabular}{lllllll}
\hline Interactive discussion before giving lessons to class & 82 & 03 & 15 & 13.635 & .000
\end{tabular}

$\begin{array}{lllllll}\text { Developing class rules in consultation with students } & 62 & 02 & 35 & 27.248 & .000\end{array}$

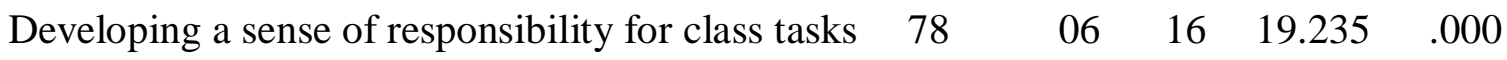

Passionate about the classroom

Taking time to know students individually

Assigning roles to students for managing classroom 59

Assigning individual, pair and group work

Respect to the questions and responses of students
72

57

59

63

08

2

11.056

.000

$\begin{array}{llll}06 & 16 & 17.549 \quad .000\end{array}$

$\begin{array}{lllllll}\text { Jokes and humor to keep students happy \& engaged } & 64 & 11 & 25 & 12.625 & .000\end{array}$ 
Body language to overcome disrupting behavior

Avoiding corporal punishment during classes
58

05

37

$19.342 \quad .000$

$\begin{array}{lllll}64 & 03 & 33 & 22.563 & .000\end{array}$

Secondary school instructors' classroom management strategies are outlined in Table-1.

In the classroom, $82 \%$ of teachers agree that interactive discussion is an important part of preparing lessons, $62 \%$ agree that class rules are developed in consultation with students, $78 \%$ agree that students should feel responsible for class tasks, $72 \%$ agree that they are passionate about their classrooms, and 57\% agree.

It shed light on the methods used by secondary school instructors to maintain order in the classroom. Prior to teaching their classes, teachers at the secondary level engage their students in interactive discussions; they develop class rules in consultation with their students, and they cultivate a sense of responsibility among their students; they spend time getting to know their students individually, assigning roles and responsibilities to each student, and assigning individual, pair, and group work. It is forbidden for them to use physical punishment in their classrooms.

Table 2

Problems in Classroom Management Practices of Secondary Schools' teachers

\begin{tabular}{llllcc}
\hline Statements & A & UD & D & $\chi^{2}$ & P \\
\hline Establishing rapport with in the beginning of classes & 66 & 13 & 21 & 18.642 & .000 \\
Students don't take an interest in activities of classes & 24 & 12 & 64 & 17.352 & .000 \\
Students make a noise during lessons in classes & 07 & 09 & 84 & 13.632 & .000 \\
Sometimes, I myself forget about classroom rules & 19 & 15 & 66 & 12.463 & .000 \\
Difficulty in developing sense of responsibility & 17 & 11 & 72 & 37.532 & .000 \\
Difficulty to use body language for managing classes & 32 & 07 & 61 & 11.356 & .000 \\
Anger on students showing disruptive behavior & 42 & 05 & 53 & 15.432 & .000 \\
\hline
\end{tabular}


Table 2 outlines issues with secondary school instructors' classroom management approaches. Participants disagreed that students don't take an interest in their levels' activities, that they make a lot of noise in their classrooms, and 72 percent disagreed that it's difficult for them to build rapport with their students at the beginning of the class.

It exposed the shortcomings of secondary school instructors' classroom management techniques. Secondary school teachers have a difficult time establishing rapport with their students in the beginning of the class; students are interested in the activities of their courses, they don't make a lot of noise in their classes, they don't forget about the classroom rules, and it's not difficult for them to establish a sense of responsibility in their students. Disruptive conduct in their classrooms is not a problem for them.

\section{DISCUSSION}

Secondary school teachers' classroom management strategies were examined in the research. The results of the poll revealed that secondary school teachers' methods of classroom management. Teachers at the secondary level use interactive discussions to develop class rules in consultation with their students, develop a sense of responsibility for class tasks among their students, are extremely enthusiastic about their classrooms, take the time to get to know their students individually, assign roles to their students for organising their classes, and assign individual, pair, and group w tasks. When teaching, they avoid using physical punishment. As Mallory (2008) observed, classroom management is a complicated process that requires an engaging curriculum, student accountability, effective teaching modelling and practical education in order to work toward conflict resolution with both individual students and the whole class. 
Teachers employ a variety of skills and approaches to ensure that their classrooms operate smoothly, without interruption, as highlighted by Elizabeth (2018). Classroom management is defined by Brophy (2006) as the sum of all actions taken to create and maintain a learning environment that is conducive to successful instruction, such as setting up the physical environment, establishing rules and procedures, and maintaining students' focus on lessons and participation in activities. Masrur (2015) also found that classroom management is the process of keeping a classroom orderly, operating smoothly, engaging students in their lessons, including students' involvement and collaboration in classroom activities, to create a productive learning environment. According to Afzal (2015), classroom management is the art of structuring a place where a group of individuals has the resources, time and reasons accessible to foster, encourage and respect their learning of a restricted set of knowledge and ideas. [vii]

Secondary school teachers' classroom management was found to be in need of improvement. For secondary school teachers, it's difficult to establish a rapport with their students at first, but they don't have a hard time developing a sense of responsibility in their students, and it's not difficult for them to create a sense of responsibility in their students, either. Disruptive conduct in their classrooms is not a problem for them. Instructors' classroom management techniques were found to be problematic by Oliver (2007), and he underlined the need of adequate classroom management training for teachers. A student's misconduct is more likely to lead to a student's academic failure if they distract the student from the proper direction. Disciplinary concerns may also be controlled via classroom management.

One of the most prevalent issues that instructors confront is a lack of discipline, according to Chandra (2015). Teachers must be willing to take on classroom supervision and long-term responsibilities since students often arrive late, are not on time, are engaged in 
courses, and more. There were also issues with classroom management that were uncovered by Regina (2007) and Oliver (2007a). They advocated for a systematic approach to teacher training and current professional development in order to improve teachers' ability to manage classrooms effectively.

\section{CONCLUSION}

The study's first objective was to find out classroom management strategies of teachers at the secondary level. The study found that at the secondary level, teachers make use of interactive discussions before giving lessons to their classes, develop class rules in consultation with their students, develop a sense of responsibility for class tasks among their students, they are very much passionate about their classrooms, they take time to know their students individually, they assign roles to their students for arranging their classes, they set individual, pair and group work to their students in the grades, they give respect to the question and responses of all the students, they make use of humor to keep their students happy and engaged in the class, they make use of the boy language to overcome disrupting behavior in their classes. They avoid corporal punishment during their lessons. The second objective of the study was to identify problems in teachers' classroom management at the secondary level. The study determined that it is difficult for secondary school teachers to make rapport with their students at the beginning of the classes. The third objective of the study was to suggest strategies for effective classroom management at the secondary level. The study suggested the process of establishing rapport through interactive discussion enable teachers to manage their classes effectively, establishing class rules in consultation with students ensure quality classroom management, teachers' passion for their classes help them in overcoming problems of managing the categories, assigning roles to students in the grades assist teachers in the direction of their classes, using body gesture help teachers in 
the management of their levels and keeping the environment of pleasure and free from fear ensure effective classroom management of teachers.

\section{Recommendations}

The study recommend the effective strategies of classroom management as establishing rapport through interactive discussion enable teachers to manage their classes effectively, establishing class rules in consultation with students ensure quality classroom management, 7teachers' passion for their classes help them in overcoming problems of managing the categories, assigning roles to students in the grades assist teachers in the direction of their classes, using body gesture help teachers in the management of their levels and keeping the environment of pleasure and free from fear ensure effective classroom management of teachers. 


\section{References}

Adams, A. (2011). Preparing teacher leaders: Perceptions of the impact of a cohort-based, job embedded, blended teacher leadership program. Teaching and Teacher Education, 27(8), $1213-1222$.

Afzal, M. T. (2015). Comparison of students' satisfaction and achievement at secondary level in Islamabad. American Journal of Educational Research, 3(12), 1524-1527.

Akomolafe, C. O. (2015). The Classroom Environment: A Major Motivating Factor towards High Academic Performance of Senior Secondary School Students in South West Nigeria. Journal of Education and Practice, 6(34), 17-21.

Brophy, J. (2006). History of research on classroom management. Handbook of classroom management: Research, practice, and contemporary issues, 17-43.

Chandra, S. (2015). Classroom management for effective teaching. International Journal of Education and Psychological Research, 4(4), 13-15.

Elizabeth, M. (2018). What Is Classroom Management. Retrieved from http://www.weareteachers.com

Galbraith, P. (1990). Stories of transition: From students to teachers. Queensland Journal of Educational Research, 13(1), 17-32.

Korpershoek, H. (2016). A meta-analysis of the effects of classroom management strategies and classroom management programs on students' academic, behavioral, emotional, and motivational outcomes. Review of Educational Research, 86(3), 643-680.

Linsin. L. (2015). "What Effective Classroom Management Really Means". Smart Classroom Management. Retrieved from. https://www.smartclassroommanagement.com. 
Mallory, M. (2008). The Future of Education: Building Capacity for Success. Delta Kappa Gamma Bulletin, 80(1).

Masrur, R. (2015). Introduction to classroom Management. Handbook of classroom management: $3-22$

Oliver, R. (2007). The relationship between language learning strategies, proficiency, age and self-efficacy beliefs: A study of language learners in Botswana. System, 35(3), 338-352.

Osama, A. A. (2012). School climate-the key to excellence. Journal of Emerging Trends in Educational Research and Policy Studies, 3(6), 950-954.

Regina, D. J and Oliver, R. M. (2007). Effective Classroom Management: Teacher Preparation and Professional Development. TQ Connection Issue Paper. National comprehensive center for teacher quality.

Rosas, C., \& West, M. (2009). Teachers Beliefs about Classroom Management: Pre-service and Inservice Teachers' Beliefs about Classroom Management. International Journal of Applied Educational Studies, 5(1). 